\title{
屈曲する冷却風を利用した一様発熱する円柱群の冷却 Cooling for Heated Cylinders Using Winding Cooling Air
}

\author{
○正 中西 正人（日立機械研究所） \\ 磯貝 正人（日立マクセル） \\ 正 大橋 繁男（日立機械研究所） \\ 中村 新吾 (日立マクセル) \\ Masato NAKANISHI and Shigeo OHASHI, Mechanical Engineering Research Laboratory, Hitachi,Ltd., \\ 502, Kandatsu, Tsuchiura, Ibaraki \\ Masato ISOGAI and Shingo Nakamura, Hitachi Maxell,Ltd. Battery R\&D Laboratory, 1-88, Ushitora 1-chome, \\ Ibaraki-shi, Osaka

\begin{abstract}
A new cooling technology for a system of arrays of heated cylinders using winding cooling air is shown. The new cooling technology decreases the temperature differences among heated cylinders. The highest temperature exists in the midst of the cylinders, because the distance between them is very small and the cylinders generate heat uniformly. The winding cooling air runs to the right of the cylinders and then along cylinders increase in flow direction.
\end{abstract} \\ their axis. The temperature differences among heated cylinders are decreased when the pitches between
}

Key Words: Cooling, Heated Cylinders, Winding Cooling Air

1.はじめに

近年の熱交換器の小型化と熱交換性能の向上の観点から、 密閉筐体内に設置された一様発熱する円柱群を冷却する問 題は重要な問題である。一㥞発熱する円柱が密集すると、 自己発熱と周りの円柱の発熱の影響により、円柱の温度は 上昇し、円柱間の温度差も大きくなる。しかし熱交換器の 性能を上げるためには円柱間の温度差をなるべく小さくす る必要がある。以上のような観点から本研究では、空冷 の熱交換器を対象として屈曲する冷却風を利用することに より密閉筐体内に設置された一様発熱する円柱群の冷却を 行う方法を提案した。そして、筐体内での円柱群の温度差 を低隇できる最適配置を求めた。

\section{2. 熱交換器の冷却風流れ}

Fig. 1 にあるように、一様発熱する円柱が筐体内に複数 本配置される。図のように筐体内に一様発熱する円柱が複 数本密集配置された場合、円柱の長手方向の中心部が最も 温度上昇が大きい。そこで、温度上昇が一番大きなところ に冷却風が当たるように、図のように筐体に冷却風の吸気 の穴 (Fig. 1 の Inlet $\left(\mathrm{A}_{1}, \mathrm{~A}_{2}\right)$ ) を設ける。そして、冷却風 の吸気口がある面と隣り、合う面に冷却風の排気口（Fig. 1 の Outlet $\left.\left(\mathrm{B}_{1}, \mathrm{~B}_{2}, \mathrm{~B}_{3}, \mathrm{~B}_{4}\right)\right)$ を設ける。

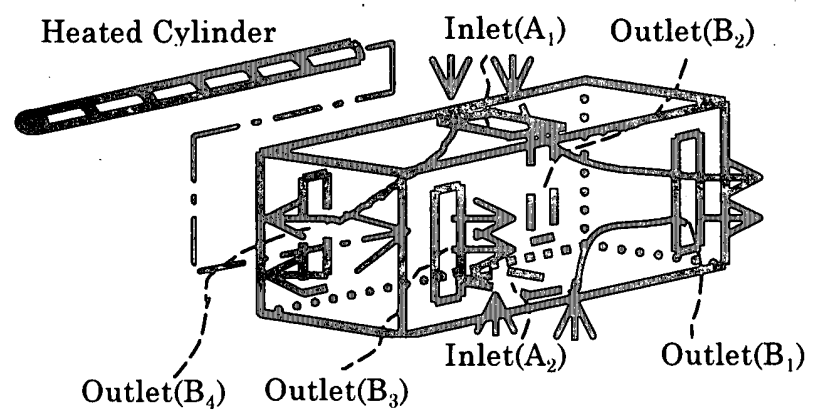

Fig. 1 Sketch of Configuration

\section{3. 円柱群の最適配列}

Fig. 2 (a)は円柱の軸に垂直な断面を示している。Fig. 2(b) は円柱群配列の対称性を考慮して、温度測定領域をあ らわしており、Fig.2 (c) は円柱の寸法と温度測定点 (1) (5) を示している。

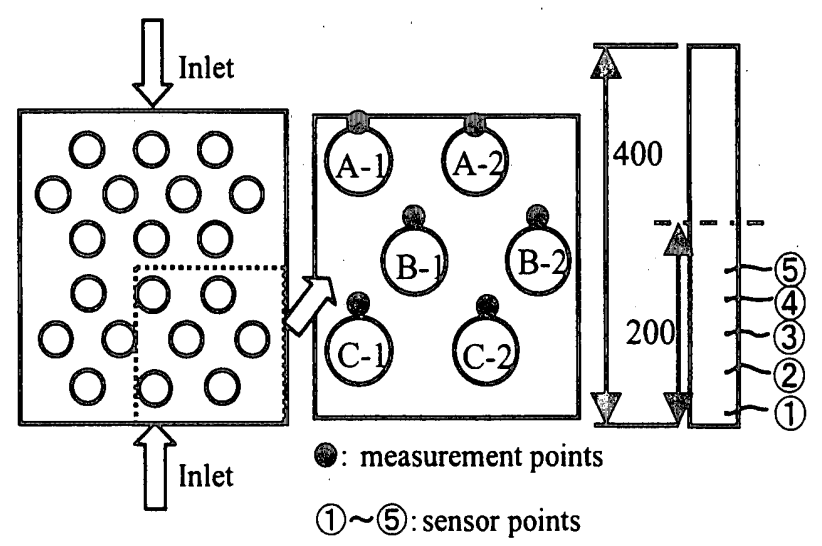

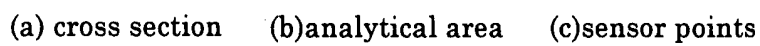

Fig. 2 Position of Heated Cylinders

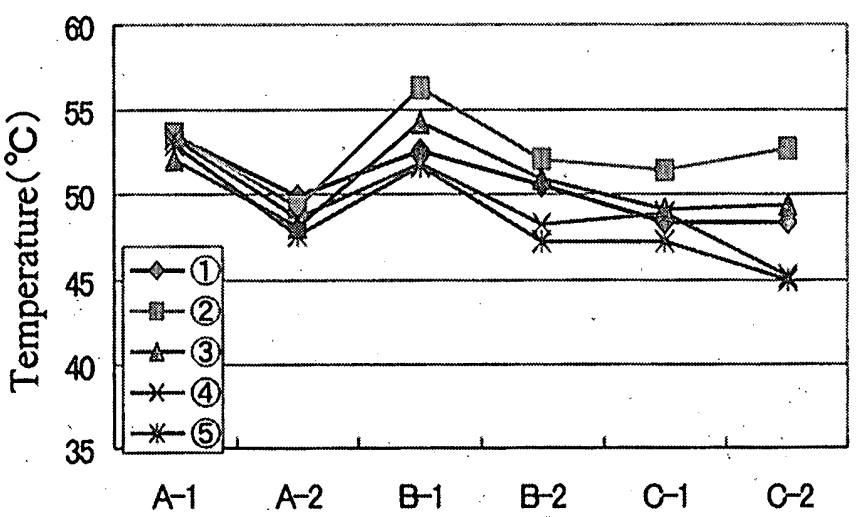

Fig. 3 Surface Temperature Distribution 
まず、筐体内の円柱群の配列として Fig.2 にあるような 千鳥配列を考えた。円柱群の配列の対称性を考慮して Fig. $2(\mathrm{a})$ の領域の網掛けの領域を温度測定の解析領域とした。 Fig. 2(c)にあるように、円柱一本の長さは $400 \mathrm{~mm}$ であり、 内径は $30 \mathrm{~mm}$ である。発熱条件は、各円柱に対して一様発 熱（18W）とし円柱表面の温度を測定した（測定ポイント は流れに対して後方下死点とする）。なお、吸気に一番近 い円柱には冷却風を整流し、かつ冷却風によって円柱が冷 え過ぎないようにガイド板が取り付けられている。Fig. 3 は、円柱の表面温度分布を示したグラフであり、グラフの 横軸は温度測定点を示しており、縦軸は円柱表面温度を示

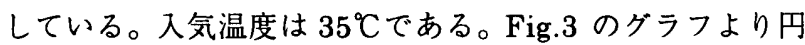
柱間の温度差が最高で約 $11^{\circ} \mathrm{C}$ と大きいため、円柱配列の最 適化を図る必要があることが分かる。

次に、筐体内の円柱群の配列の最適化を図るために、筐 体内の円柱群周りの流れに対して有限体積法をもとにした 熱流体計算を行った。熱流体計算に際し、入気温度は $20^{\circ} \mathrm{C}$ とした。検討した配列はFig.4に示すように(a)碁盤目配列、 (b)筐体中央部で 2 列配列、それ以外は 3 列配列、(c)2 列配 列の 3 種類である。また、円柱間距離は千鳥配列以外は一 定とする。図は筐体中央部断面の温度分布と速度分布を示 している。解析の結果、(a),(b)では筐体中央部の円柱の温 度上昇が大きく、(c)の場合が円柱間温度差が最も小さいこ とが分かる。これは、(a)や(b)の配列では冷却風が下流方向 に流れるにしたがって、円柱群の中に入り込まずに、筐体 側壁の方に流れていく傾向が強いために筐体中央部の円柱 まで冷却風が十分に行き渡らない。それにより筐体中央部 の円柱の温度上昇が大きくなると考えられる。そこで屈曲 した冷却風を利用することにより、冷却風は温度上昇が最 大のところに吹き付けられ、その後円柱の軸に沿って流れ 排気口より出て行く。以上の理由により円柱間の温度差を 小さくすることができる。

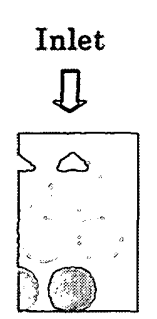

(a)

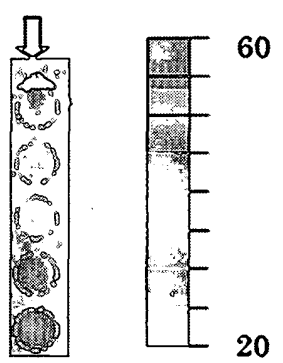

(c) Temperature $\left({ }^{\circ}\right)$
Fig. 4 Temperature and Velocity Distribution

\section{4. 熱交換器の小型化}

次に、熱交換器のサイズを今以上に小さくするために円 柱間距離について検討した。上記円柱配列は、千鳥配列を 除き円柱間距離は等しい。その結果下流方向距離が長くな るほど、風温上昇も大きくなり下流にある円柱の温度を上 昇させる。そこで、下流方向に行くにしたがって円柱間距 離を大きくすることを検討した。

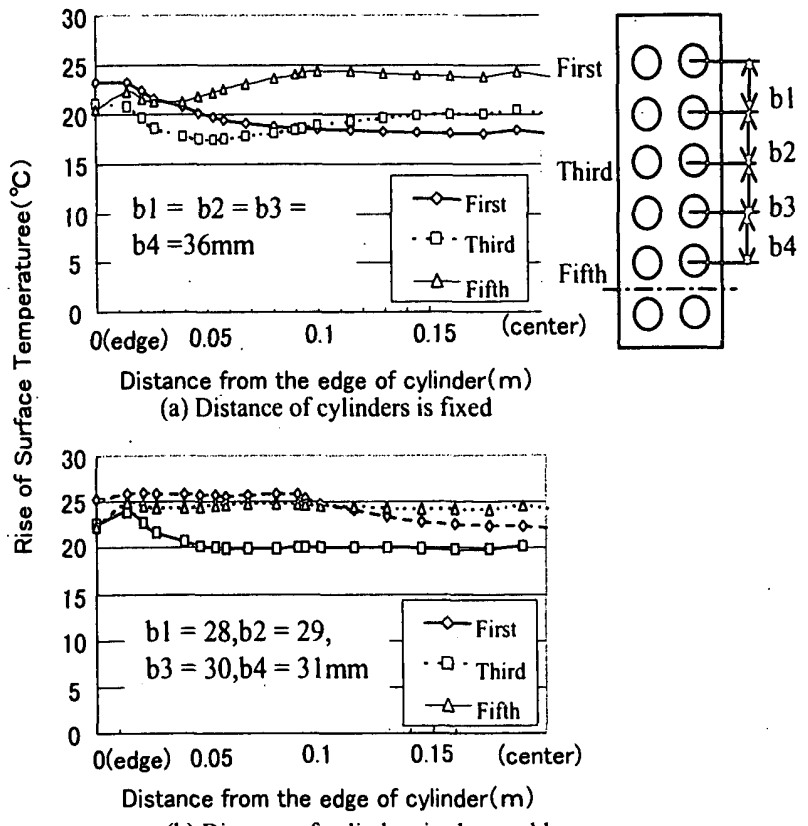

(b) Distance of cylinders is changeable

Fig. 5 Surface Temperature Distribution

Fig. 5 は円柱軸方向に対する円柱表面の温度上昇值を示 しており、円柱間距離をすべて等しくした場合と、流れ方 向に対して円柱間距離を増大させた場合についての結果を 示す。Fig.5 のグラフの横軸は円柱端部からの距離であり、 円柱の長さの半分まで表示してある。縦軸は円柱表面温度 上昇值である。表面温度を測定した円柱は、1 列目、3 列 目、5 列目の円柱とした。円柱間距離以外の計算条件は Fig.4の(c)の場合に準拠する。円柱間距離が等しい場合の 距離は $36 \mathrm{~mm}$ であり、円柱間距離が上流側に行くほど小さ くなる場合は、 b1 $=28 \mathrm{~mm}, \mathrm{~b} 2=29 \mathrm{~mm}, \mathrm{~b} 3=30 \mathrm{~mm}, \mathrm{~b} 4=$ $31 \mathrm{~mm}$ とした。Fig. 5 のグラフから円柱間距離を上流側に 行くほど小さくしたことにより、円柱端部の一部分を除い て、円柱間の温度差は円柱間距離が等しい時と比べて低減 されていることが分かる。これにより下流側の円柱に対す るその一つ上流の円柱の発熱による影響を小さくすること できる。

5. まとめ

密閉筐体内に設置された円柱群の冷却を考察し、以下の ようなことが分かった。(1)密閉された筐体に設置された円 柱群の冷却には屈曲した冷却風が有効である。(2)筐体内の 円柱群の配列に関しては、今回検討した中では 2 列配列が 円柱間温度差が最も小さかった。(3)円柱間距離を上流側に 行くほど小さくすることにより円柱間の温度差をさらに低 減できることが分かった。

\section{参考文献}

(1)伝熱工学資料改訂第 4 版, 日本機械学会, (1991), 244. 